\title{
Assessing Sediment-Nutrient Export Rate and Soil Degradation in Mai-Negus Catchment, Northern Ethiopia
}

\author{
Gebreyesus Brhane Tesfahunegn ${ }^{1,2}$ and Paul L. G. Vlek ${ }^{2}$ \\ ${ }^{1}$ College of Agriculture, Aksum University, Shire Campus, P.O. Box 314, Shire, Ethiopia \\ ${ }^{2}$ Center for Development Research, University of Bonn, Walter-Flex-Straße 3, 53113 Bonn, Germany \\ Correspondence should be addressed to Gebreyesus Brhane Tesfahunegn; gebre33@gmail.com
}

Received 13 April 2013; Accepted 12 May 2013

Academic Editors: T. J. Cutright, J. A. Entry, M. Goss, C. Martius, and W. R. Roy

Copyright ( 2013 G. B. Tesfahunegn and P. L. G. Vlek. This is an open access article distributed under the Creative Commons Attribution License, which permits unrestricted use, distribution, and reproduction in any medium, provided the original work is properly cited.

\begin{abstract}
Even though soil degradation challenges sustainable development, the use of degradation indicators such as nutrient export (NE) and nutrient replacement cost is not well documented at landform level. This study is aimed to investigate the extent of soil degradation, NE rates, and their replacement cost across landforms in the Mai-Negus catchment, northern Ethiopia. Different erosion-status sites (aggrading, stable, and eroded) in the landforms were identified, and soil samples were randomly collected and analysed. Nutrient export, replacement cost, and soil degradation were calculated following standard procedures. This study showed that soil degradation in the eroded sites ranged from 30 to $80 \%$ compared to the corresponding stable site soils, but the highest was recorded in the mountainous and central ridge landforms. Average NE of 95, 68, 9.1, 3.2, 2.5, and $0.07 \mathrm{~kg} \mathrm{ha}^{-1} \mathrm{y}^{-1}$ for soil calcium, carbon, nitrogen, potassium, magnesium, and phosphorus, respectively, was found from the landforms. Significantly strong relationships between NE and sediment yield in the landforms were observed. Annual nutrient replacement costs varied among the landforms though the highest was in the reservoir (€9204 in May 2010). This study thus suggests that while introducing antierosion measures, priority should be given to erosion sources to the reservoir such as mountainous and central ridge landforms.
\end{abstract}

\section{Introduction}

Soil erosion is a challenge for sustainable agricultural development in many developing countries $[1,2]$. The problem is more serious in the Ethiopian highlands such as the Tigray region [3-5]. Inappropriate agricultural practices, high population pressure from human and livestock, higher rainfall intensity, and rugged topography have been reported as the main facilitators for having severe erosion [6, 7].

In the Tigray region, average soil loss by erosion on cultivated land is more than $49 \mathrm{tha}^{-1} \mathrm{y}^{-1}$ [8], which exceeds the average soil loss of $42 \mathrm{tha}^{-1} \mathrm{y}^{-1}$ for Ethiopia as a whole [3]. Such soil loss through water erosion is almost always accompanied by losses of essential soil nutrients. Erosion is selective for fine soil particles, which are relatively richer in soil nutrients $[9,10]$. In line with this, Stoorvogel and Smaling [11] and UNDP [12] reports showed that compared to rates in sub-Saharan Africa, Ethiopia has the highest soil nutrient outflow rates of $60 \mathrm{~kg} \mathrm{ha}^{-1}\left(30 \mathrm{~kg} \mathrm{ha}^{-1}\right.$ nitrogen and $15-20 \mathrm{~kg} \mathrm{ha}^{-1}$ phosphorous), while inflows from fertilizers are very low $\left(<10 \mathrm{~kg} \mathrm{ha}^{-1}\right)$. In the long term, such soil nutrient losses by erosion adversely affect soil productivity of the source areas and are expected to lead to an increase in nutrients in the deposition areas $[9,10]$.

Nutrient export rates can well describe the level of soil nutrient degradation in the source soils and the enrichments in the deposition sites [13]. Despite such utility, the rate of soil nutrient export as a means of assessing degradation from different landforms in a catchment considering different erosion-status sites has not yet received research attention. However, such research is pertinent to the development of site-specific strategies targeting the source sites.

Other studies have shown that erosion and deposition processes can significantly contribute to the variability of fine soil particles and the associated nutrient exports from catchment topography $[14,15]$. Soil erosion and sediment 
TABLE 1: Biophysical description of the landforms in the Mai-Negus catchment, northern Ethiopia.

\begin{tabular}{|c|c|c|c|c|c|c|c|c|c|c|}
\hline \multirow{2}{*}{ Landform } & \multirow{2}{*}{$\operatorname{Area}^{\mathrm{e}}(\%)$} & \multicolumn{4}{|c|}{ Land-use cover $(\%)^{\mathrm{a}}$} & \multicolumn{3}{|c|}{ Lithology $\%^{\mathrm{b}}$} & \multirow{2}{*}{ Slope, $\operatorname{deg}^{\mathrm{c}}$} & \multirow{2}{*}{ Elevation, $\mathrm{m}^{\mathrm{d}}$} \\
\hline & & Arable & Grazing & Bush and Wood ${ }^{\mathrm{f}}$ & Others $^{\mathrm{g}}$ & $\mathrm{BM}$ & LP & ST & & \\
\hline Rolling hills & 10.0 & 80 & 10 & 4 & 6 & 100 & n.a. & n.a. & $3-16$ & $2150-2240$ \\
\hline Mountainous & 14.5 & 36 & 34 & 26 & 4 & 35 & 65 & n.a. & $4-79$ & $2350-2650$ \\
\hline Central ridge & 25.5 & 70 & 13 & 5 & 12 & 5 & 95 & n.a. & $3-25$ & $2230-2450$ \\
\hline Valley & 19.9 & 65 & 31 & 2 & 2 & 77 & 23 & n.a. & $0-6$ & $2070-2100$ \\
\hline Plateau & 9.8 & 47 & 16 & 30 & 7 & 58 & 42 & 9 & $3-10$ & $2500-2550$ \\
\hline Escarpment & 19.1 & 47 & 31 & 14 & 5 & 84 & 7 & n.a. & $3-30$ & $2270-2540$ \\
\hline Reservoir & 1.2 & n.a. & n.a. & n.a. & n.a. & 100 & n.a. & n.a. & 0 & 2060-2080 \\
\hline
\end{tabular}

BM: basic metavolcanics; LP: lava pyroclastic; ST: sandstone; n.a.: not applicable.

${ }^{\mathrm{a}}$ The proportion of the land covers was derived from a Landsat image of November 2007 overlaid by the landform map.

${ }^{b}$ This was derived by overlaying the landform map with the geology map of Ethiopia.

${ }^{\mathrm{c}}$ Developed from digital elevation model (DEM).

${ }^{\mathrm{d}}$ Derived from DEM.

${ }^{\mathrm{e}}$ Total catchment area is $12.40 \mathrm{~km}^{2}$, and reservoir area is $0.15 \mathrm{~km}^{2}$.

${ }^{\mathrm{f}}$ Includes closed area, plantations, and natural vegetation.

${ }^{\mathrm{g}}$ Includes settlements, rock-out crop, and marginalized areas.

delivery processes, which are responsible for high sediment transport and the associated export of sediment-bound nutrients to deposition areas in a catchment, are influenced by landscape characteristics [13]. In line with this, studies on nutrient balances in Ethiopia indicate that the balance at farm level is more positive than plot level $[11,16,17]$, while losses from some fields may be of benefit to other fields. This may be attributed to the effect of nutrient redistribution by erosiondeposition processes or to active nutrient transfers by farmers.

Studies of erosion-induced changes in soil properties at the field scale have constantly shown that soil texture, surface soil organic carbon, nitrogen, and phosphorus concentrations are higher in areas of soil deposition compared to areas of soil removal by erosion [18]. Assessing the effect of erosion on soil properties variability as a result of nutrient export from catchment landforms can provide more meaningful results. This study aims to (1) assess soil nutrient depletion and soil physical degradation comparing the eroded and stable-sites soil, (2) examine the rate of soil nutrient export considering the aggrading and eroded erosion-status sites in the landforms of the Mai-Negus catchment, northern Ethiopia, and (3) quantify the costs of soil degradation associated with nutrient losses through water erosion at landform and catchment scale and extrapolate the findings to the Tigray region and highlands of the country.

\section{Materials and Methods}

2.1. Study Site. This study was conducted in the MaiNegus catchment in the Tigray region of northern Ethiopia (Figure 1). The catchment has an area of 1240 ha and altitudes ranging from 2060 to $2650 \mathrm{~m}$ a.s.l. It has a mean annual temperature of $22^{\circ} \mathrm{C}$ and precipitation of $700 \mathrm{~mm}$. Most of the rainfall $(>70 \%)$ occurs in July and August. Land use is predominantly arable, with teff (Eragrostis tef) being the major crop along with different-sized areas of pasture land and scattered patches of trees, bushes, and shrubs. The major rock types are lava pyroclastic and metavolcanic. Soils are mainly leptosols on very steep positions, cambisols on middle to steep slopes, and vertisols on flat areas.

2.2. Terrain Assessment. In this study, field reconnaissance surveys were carried out to gain an overall image of the catchment characteristics (Table 1). Data were collected from June to December 2009. The landforms in the catchment (Figure 1) were developed in ArcGIS software using field survey-based data in combination with the information from the topographic map. Considering elevation, slope, geology, and geomorphologic characters (surface flows, alluvial, and colluvial deposition), the catchment topography is classified into six main landforms (Figure 1), namely, valley (19\% of the catchment area), plateau (8\%), rolling hills (9\%), central ridge (27\%), escarpments (29\%), and mountainous (6\%).

The reservoir was considered a separate landform in the catchment and is located at the toeslope of the catchment. Sediment deposition in the reservoir was used to estimate the level of soil degradation, nutrient export rate, and the associated replacement costs from the entire catchment. Deposition sites in the other landforms of the catchment were used to assess soils deposited on the way to the reservoir after being transported from the original place towards the outlets of the landforms. Generally, during the field survey, three sites, namely, deposition/aggrading, stable, and eroded erosion-status sites in the six landforms of the study catchment were identified using standard geomorphological procedures of erosion-deposition indicators.

2.3. Erosion-Status Site Selection and Soil Sampling Points. Representative erosion-status sites (aggrading, stable, and eroded) and the corresponding soil sampling points (Figure 1) were selected in four steps. A reconnaissance survey on land use, lithology, soil types, slopes, and elevation ranges of the landforms (Table 1), followed by informal discussions with farmers and development agents to gain insight on land use history as well as land- and crop-management 


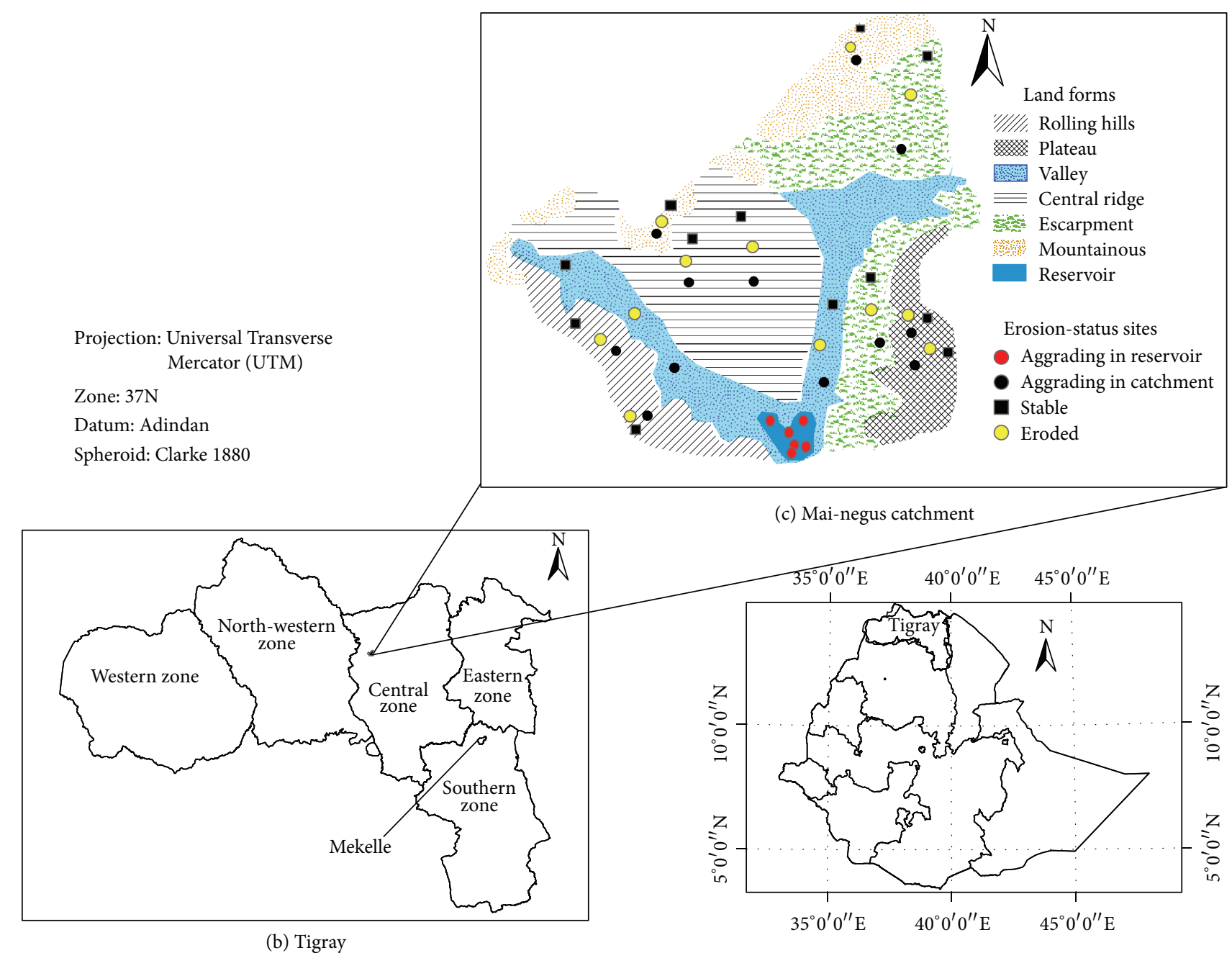

(a) Ethiopia

Figure 1: Study areas: Ethiopia (a), Tigray (b), and Mai-Negus catchment, (c) (landforms) with representative soil sampling points for aggrading (deposition), stable, and eroded erosion-status sites.

practices, was carried out. Subsequently, erosion-status sites were selected using soil morphology such as thickness of alluvial/colluvial deposits and degree of truncation of the top soil horizon (soil profile) and erosion indicators (rills, gullies, surface sheet wash, exposure of roots and stones, and depositions). In the stable sites, slopes are flat to gentle, and there is little evidence of soil truncation or deposition, indicating that soil loss and gain is more or less balanced. The eroded sites were identified based on a combination of erosion indicators and features associated with soil profile truncation. When aggrading sites were selected, depression areas that received sediment from upper slopes and erosion channels were considered. Finally, representative soil/sediment sampling points of the erosion-status sites were located and georeferenced. Composite samples were randomly collected from sampling grid areas ranging from 150 to $300 \mathrm{~m}^{2}$ for each soil sampling point in the erosion-status site. Each site had two soil sampling points, and 5-8 composite samples were collected at $0-20 \mathrm{~cm}$ soil depth. The composite samples (weighted 500 gm each) were pooled and mixed thoroughly in a basket manually. A subsample of $500 \mathrm{~g}$ was taken for analysis after being air dried and sieved to pass through $2 \mathrm{~mm}$ sieve. A total of 36 soil samples (6 landforms $\times 3$ erosionstatus sites in each landfrom $\times 2$ sampling points), and 6 sediment samples from the reservoir resulted in a grand total of 42 samples for analysis.

The sampling point selection in the reservoir took into account the sediment depth variability, flow source, outflow, and length of time where water was in the reservoir. There was no water at the selected sampling points in the reservoir on the second week of June 2009. For the sampling points identified in the reservoir, 6 representative pits with depths ranging from 1.0 to $2.5 \mathrm{~m}$ were dug down to reach the interface with the original soil. Then three composite samples were collected from the entire depth of each pit. The samples from each pit were pooled and mixed thoroughly in a basket, and a subsample of $500 \mathrm{~g}$ was taken for analysis. 
2.4. Soil/Sediment Analysis. Soil/sediment samples were determined for texture using the Bouyoucos hydrometer method [19], bulk density (BD) by core method [20], organic carbon by Walkley-Black method [21], available phosphorus (Pav) by Olsen method [22], and total nitrogen (TN) and total phosphorus (TP) by Kjeldahl Digestion method [23]. Cation exchange capacity (CEC) is determined by ammonium acetate extraction buffered at pH 7 [24]. Exchangeable bases (calcium, Ca; magnesium, Mg; potassium, K) were analyzed after extraction using $1 \mathrm{M}$ ammonium acetate at $\mathrm{pH}$ 7.0. Iron $(\mathrm{Fe})$ and zinc $(\mathrm{Zn})$ were determined using $0.005 \mathrm{M}$ diethylene triamine pentaacetic acid extraction by the method described in Baruah and Barthakur [25].

2.5. Estimation of the Extent of Soil Degradation. Soil nutrient and soil physical degradation were assessed based on the differences in the content of the soil nutrients and fine soil particles in the stable and eroded sites. The stable site soils were used as a reference. The magnitude of degradation was similarly calculated as the ratio of the difference in the content of the soil properties between the stable and eroded sites to the reference soils.

2.6. Quantification of Nutrient Export Rate Associated with Water Erosion. The nutrient export (NE) to the reservoir associated with runoff and sediment and to the hypothetical deposition areas on the way to the reservoir at the outlets of the landforms was calculated using equations defined in Verstraeten and Poesen [26] as

$$
\begin{gathered}
\mathrm{NE}_{r}=\frac{\mathrm{SM} * \mathrm{NC}}{A * Y * \mathrm{NTE} * 10}, \\
\mathrm{SM}=\mathrm{SV} * \mathrm{dBD}, \\
\mathrm{NE}_{l}=\mathrm{SSY}\left(\frac{\mathrm{NC}}{\mathrm{NTE} * 10}\right), \\
\mathrm{SSY}=\frac{\mathrm{SM}}{A * Y},
\end{gathered}
$$

where $\mathrm{NE}_{r}$ is the nutrient export $\left(\mathrm{kg} \mathrm{ha}^{-1} \mathrm{y}^{-1}\right)$ from the entire catchment to the reservoir, $\mathrm{NE}_{l}$ is the nutrient export $\left(\mathrm{kg} \mathrm{ha}^{-1} \mathrm{y}^{-1}\right)$ to the outlet of each landform in the catchment, $\mathrm{SM}$ is total sediment mass (ton), NC is average nutrient content (ton of nutrient per $\mathrm{kg}$ of sediment), $A$ is drainage area (ha), $Y$ is duration (age) of sediment accumulation which was 16 years for the reservoir, SV is total sediment volume $\left(\mathrm{m}^{3}\right), \mathrm{dBD}$ is dry bulk density (ton $\left.\mathrm{m}^{-3}\right)$, and SSY is area-specific sediment yield $\left(\mathrm{t} \mathrm{km}^{-2} \mathrm{y}^{-1}\right)$. The nutrient trap efficiency (NTE) of the reservoir or the depositional areas in the landforms is assumed to be equal to sediment trap efficiency (STE in \%). The parameters used for the calculation of nutrient export rates are presented in Table 2.

An empirical model was used for the verification of the information gathered through discussions with the farmers on the condition of outflow from the reservoir for

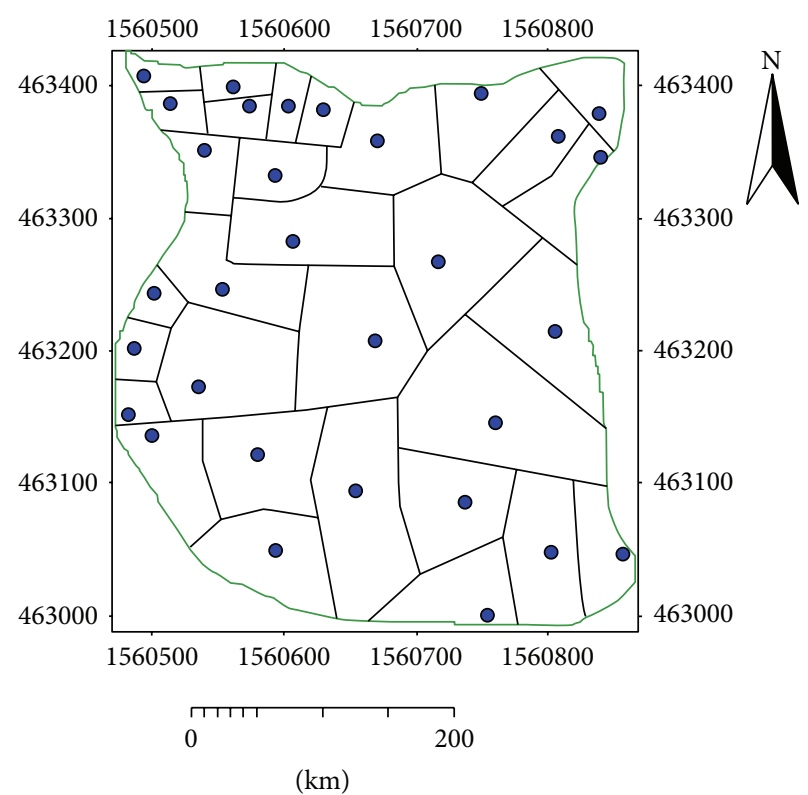

FIGURE 2: Spatial distribution of sediment depths measured (blue dots) and polygons (areas) influenced by the dots in the reservoir of the Mai-Negus catchment, northern Ethiopia.

determining STE. The STE was calculated on the basis of the formula given in Verstraeten and Poesen [26] as

$$
\mathrm{STE}=100\left(1-\frac{1}{1+0.0021 D(C / A)}\right),
$$

where $C$ is reservoir storage capacity $\left(\mathrm{m}^{3}\right)$ and $A$ is catchment area $\left(\mathrm{km}^{2}\right)$. $D$ has constant values ranging from 0.046 to 1 with a mean value of 0.1 . In this study, considering the scarcity of local information for defining a value of $D$, a $D$ value of 0.1 was used.

The nutrient trap efficiency was considered to be equal to the sediment trap efficiency (STE) as (1) no spillage occurred except in one season in 2007, (2) the stored water is used for irrigation during the dry period once the sediments and nutrients have settled in the reservoir, and (3) soil nutrients are mainly transported bound to sediment, as soil nutrient solubility is low in the soils of the region [13]. Such assumptions imply that both nutrients and sediments are assumed to have the same chance of being trapped in the reservoir. Similar assumptions were also used in past studies while estimating the STE of different reservoirs in the Tigray region catchments [13].

The area-specific sediment yield (SSY) of the reservoir was determined based on the field survey of sediment depth measured. Spatially distributed sediment depths (bold dots) were located within the reservoir (Figure 2) based on visual observation of sediment size, pattern, and depth. Augering was also conducted to assess the sediment thickness (pit depth). Differentiation between bottom in situ material and newly deposited sediment was easy due to sediment stratification. The sampling pits were georeferenced and then interpolated using Thiessen polygonsin ArcGIS to calculate 
TABLE 2: Sediment yield and other related parameters of the different landforms in the Mai-Negus catchment, northern Ethiopia.

\begin{tabular}{|c|c|c|c|c|c|c|}
\hline Landform & $\mathrm{SV}\left(\mathrm{m}^{3}\right)$ & SM (t) & $\mathrm{A}\left(\mathrm{Km}^{2}\right)$ & $\mathrm{dBD}\left(\mathrm{t} \mathrm{m}^{-3}\right)$ & STE (\%) & $\operatorname{SSY}\left(\mathrm{t} \mathrm{Km}^{-2} \mathrm{y}^{-1}\right)$ \\
\hline Rolling hills & 1,024 & 1,566 & 1.25 & 1.53 & 63 & 1,254 \\
\hline Mountainous & 3,579 & 5,762 & 1.82 & 1.61 & 55 & 3,165 \\
\hline Central ridge & 4,761 & 7,568 & 3.20 & 1.59 & 57 & 2,366 \\
\hline Valley & 4,327 & 5,884 & 2.52 & 1.36 & 66 & 2,335 \\
\hline Plateau & 965 & 1,408 & 1.21 & 1.46 & 62 & 1,164 \\
\hline Escarpment & 3,212 & 4,786 & 2.40 & 1.49 & 69 & 1,994 \\
\hline Reservoir $^{\mathrm{a}}$ & 343,776 & 388,467 & 12.40 & 1.13 & 99 & 1,958 \\
\hline Average & 51,663 & 59,349 & 3.54 & 1.45 & 67 & 2,034 \\
\hline Standard deviation & 128,818 & 145,143 & 3.07 & 0.17 & 14.80 & 690 \\
\hline
\end{tabular}

SV: annual sediment volume; SM: annual sediment mass; A: drainage area; dBD: dry bulk density; STE: sediment trap efficiency; SSY: area specific sediment yield.

${ }^{a}$ Sediment in volume and mass is total amount of sediment accumulated in the reservoir over 16 years (1994-2009). SSY coming from the whole catchment area $\left(12.40 \mathrm{~km}^{2}\right)$ was calculated after the depth of the spatially distributed pits opened in the reservoir sediment was measured, georeferenced, and then interpolated through Thiessen polygons in a GIS environment.

SSY for each polygon using the equation defined in Tamene [8]. However, the SSY of the landforms in the study catchment was estimated from the Soil and Water Analysis Tool (SWAT) model simulation result of the subbasins. The model takes into account transfers of SSY using routing procedure between landforms, for example, from mountain to plain land. The SWAT model was calibrated, validated, and assessed for uncertainty using Nash-Sutcliffe coefficient $(>0.5)$ and coefficient of determination $(>0.6)$. Such model efficiency values indicated that the model is adequate for prediction in the study catchment conditions. The details of the model evaluation result can be found in Tesfahunegn [27].

Distributed sediment delivery ratio (SDR) estimation is necessary for different landscape positions (landforms). A simple approach to estimate SDR is defined by Tamene [8] as

$$
\mathrm{SDR}_{i}=\left(\frac{\mathrm{HD}_{i}}{\mathrm{SL}_{i}}\right) 10^{\wedge},
$$

where $\mathrm{SDR}_{i}=\mathrm{SDR}$ of a land cell (landform); $\mathrm{HD}_{i}=$ elevation difference between a land cell at a given point and the associated main stream outlet cell in the landform; $\mathrm{SL}_{i}$ $=$ length of the flow path between the inlet and the main channel outlet of a landform. To estimate the distributed SDR values for each landform using (3), the study catchment was first subdivided into different landforms. The STE of the landforms was found after the SDR was estimated and assumed to be equivalent to the sediments not delivered into the outlets of the landforms.

Annual sediment mass deposition (SM, ton) was calculated by multiplying SSY $\left(\mathrm{t} \mathrm{km}^{-2} \mathrm{y}^{-1}\right)$ by the area of each landform. There was no sediment trapping structure in the six landforms during the study period. In the presence of impoundments, the trap efficiency can be higher than the assumption used in this study. Generally, the procedure for estimating sediment trap efficiency at the outlets of the landforms was considered to be similar to the sediment not delivered, and comparison of SM among the landforms for priority setting is thus scientifically unbiased. In addition, in the absence of other reliable alternative procedures for determining STE in landforms within catchments and subcatchments without reservoirs and ungauged measurements, the use of the present approach and assumption can support for site-specific decision-making processes.

The measured sediment volumes were converted to sediment masses using the mean value of the bulk density determined for each landform. To determine the mean bulk density, duplicate undisturbed sediment core samples were collected from the six pits at the dry-bed reservoir. For the other landforms, mean bulk density was determined using core samples collected from the deposition sites at $0-20 \mathrm{~cm}$ depth.

2.7. Costs of Nutrient Loss through Erosion. To assess the costs of sediment-associated nutrient losses, a "replacement cost" approach has already been applied to compare among different catchments $[13,28]$. However, there is still an information gap with regard to the application of such approach to landforms within a catchment with and without reservoir. In this study, the loss of nutrients associated with water erosion was calculated using the equivalent price of commercial fertilizers, for example, urea and di-ammonium phosphate (DAP). First, the nitrogen $(\mathrm{N})$ and phosphorous $(\mathrm{P})$ export rate from each landform and the entire catchment to the reservoir was assessed. Second, the $\mathrm{P}$ value was converted to an equivalent $\mathrm{P}_{2} \mathrm{O}_{5}$ value and then to DAP fertilizer. Third, the amount of $\mathrm{N}$ for DAP was estimated from the $\mathrm{N}$ exported. Fourth, the remaining $\mathrm{N}$ exported was converted to urea fertilizer. Finally, the cost of nutrient export was estimated in terms of the money required for replacing the nutrient losses as urea and DAP fertilizer. The local price in May 2010 for urea and DAP was used to estimate the replacement cost of the exported nutrients. The price of $100 \mathrm{~kg}$ of DAP was 360 Ethiopian Birr currency (ETB) (€21.18), and that of $100 \mathrm{~kg}$ urea was $320 \mathrm{ETB}(€ 18.82)$. The replacement cost in the catchment was projected to the scale of the Tigray region and Ethiopian highlands. 


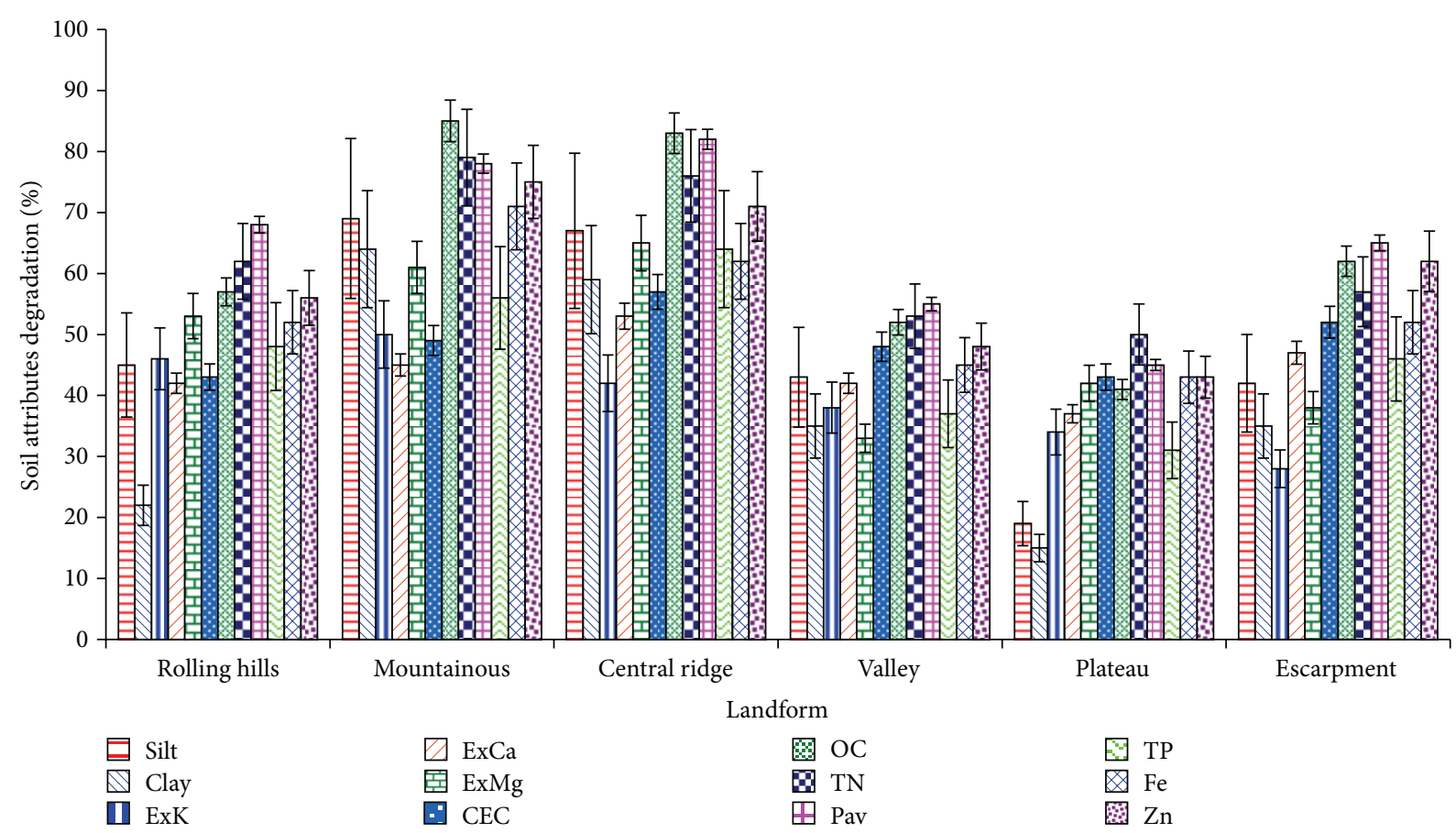

Figure 3: Extent of soil degradation using selected soil properties (\%) in the landforms of Mai-Negus catchment, northern Ethiopia. Y Error bars are standard deviation of samples. Note: ExK, exchangeable potassium; ExCa, exchangeable calcium; ExMg, exchangeable magnesium; CEC, cation exchange capacity; OC, organic carbon; TN, total nitrogen; Pav, available phosphorus; TP, total phosphorus; Fe, iron; Zn, zinc.

2.8. Data Analysis. Data were subjected to one-way analysis of variance (ANOVA) using SPSS 18.0 release software [29]. The landform was considered as a group variable. Normality and homogeneity assumptions of ANOVA were checked. Means were separated using the least significant difference (LSD) and tested by all-pairwise comparisons at probability level, $P \leq 0.05$. Both SPSS and Excel sheets were also used for descriptive statistics and regression analysis.

\section{Results and Discussion}

3.1. Extent of Soil Degradation across the Landforms. To assess the extent of soil degradation in the landforms, soil parameters in the eroded sites were compared with that of the stable site soils (reference soils). Soil parameters values below the level of the stable site soils indicated that the extent of soil degradation is higher than aggradation. Accordingly, a high level of soil degradation was observed across the landforms for all soil parameters, but the highest was observed in the mountainous and central ridge landforms (Figure 3). The level of soil degradation for most soil indicators in the eroded sites of the central ridge and mountainous landforms ranged from 50 to $80 \%$ compared to the corresponding stable site soils. The soil nutrients of OC, TN, and Pav were among the most degraded parameters across the landforms. In agreement to this study, the finding in Haileslassie et al. [30] indicated that soil erosion accounted for losses of TN by $70 \%$ and Pav by $80 \%$ while assessing nutrient balance at a regional scale in Ethiopia.
The landforms with less degraded soils were the plateau followed by the valley and escarpment, where soil nutrients degraded in the range of $30-40 \%$ as compared to the stable site soils (Figure 3 ). The magnitude of physical degradation as silt was higher than that of clay and ranged from $19 \%$ in the plateau to $69 \%$ in the mountainous and central ridge landforms. The reason could be attributed to higher susceptibility of silt to erosion processes. However, this study showed that soil nutrient degradation is higher than soil physical degradation in the study catchment landforms. Thus, appropriate interventions that improve the soil nutrients should be introduced in the landforms.

3.2. Evaluation of Nutrient Export Rate Associated with Sediment Yield. This study showed that soil nutrient export rates were significantly $(P \leq 0.05)$ varied among most landforms (Table 3). On average, nutrient export rates $\left(\mathrm{kg} \mathrm{ha}^{-1} \mathrm{y}^{-1}\right)$ of 95 for $\mathrm{Ca}, 68$ for $\mathrm{OC}, 9.1$ for $\mathrm{TN}, 3.2$ for $\mathrm{K}, 2.5$ for $\mathrm{Mg}$, and 0.07 for Pav were observed in the landforms. But the export rate from the entire catchment to the reservoir was significantly higher than the average of all landforms and even the values of the individual landforms (Table 3 ). This could be attributed to the fact that the reservoir is the largest sink for sedimentattached soil nutrients exported from the hotspot erosion sources in the entire catchment. This was followed by the valley, which received sediment coming from the upstream landforms. Sediment from all other landforms is routed through the valley, and then finally to the reservoir. Generally, this study indicated that from the erosion source areas, large 
TABLE 3: Nutrient export rate associated with sediment yield across the landforms in Mai-Negus catchment, northern Ethiopia.

\begin{tabular}{|c|c|c|c|c|c|c|}
\hline \multirow{2}{*}{ Landform } & \multicolumn{6}{|c|}{ Rate of nutrient export $\left(\mathrm{kg} \mathrm{ha}^{-1} \mathrm{y}^{-1}\right)$} \\
\hline & $\mathrm{K}$ & $\mathrm{Ca}$ & $\mathrm{Mg}$ & $\mathrm{OC}$ & $\mathrm{TN}$ & Pav \\
\hline Rolling hills & $1.36 \mathrm{e}$ & $35.43 \mathrm{e}$ & $1.21 \mathrm{~d}$ & $23.76 \mathrm{e}$ & $4.23 \mathrm{~d}$ & $0.032 \mathrm{de}$ \\
\hline Mountainous area & $3.81 b$ & $126.8 \mathrm{c}$ & $2.91 b$ & $86.49 b$ & $10.36 \mathrm{~b}$ & $0.087 \mathrm{c}$ \\
\hline Central ridge & $3.73 b$ & $115.7 c$ & $2.82 \mathrm{~b}$ & $57.73 c$ & $8.66 \mathrm{bc}$ & $0.096 b$ \\
\hline Valley & $3.91 b$ & $135.9 \mathrm{~b}$ & $2.98 \mathrm{~b}$ & $98.11 \mathrm{~b}$ & $11.56 \mathrm{~b}$ & $0.102 b$ \\
\hline Plateau & $1.52 \mathrm{~d}$ & $25.87 \mathrm{e}$ & $0.79 \mathrm{e}$ & $29.39 \mathrm{e}$ & $3.92 \mathrm{~d}$ & $0.022 \mathrm{e}$ \\
\hline Escarpment & $1.97 \mathrm{c}$ & $57.27 d$ & $2.2 \mathrm{c}$ & $42.37 d$ & 7.11c & $0.041 \mathrm{~d}$ \\
\hline Reservoir & $6.14 \mathrm{a}$ & $166.8 \mathrm{a}$ & $4.79 \mathrm{a}$ & $135.7 \mathrm{a}$ & $17.74 \mathrm{a}$ & $0.135 \mathrm{a}$ \\
\hline Average & 3.21 & 94.8 & 2.53 & 67.6 & 9.08 & 0.074 \\
\hline Standard deviation & 1.71 & 54.8 & 1.32 & 40.9 & 4.78 & 0.042 \\
\hline
\end{tabular}

K: potassium; Ca: calcium; Mg: magnesium; OC: organic carbon; TN: total nitrogen; Pav: available phosphorus.

amounts of soil nutrients are exported to the deposition sites in the same or other landforms. Such erosion processes are aggravated by terrain characteristics (e.g., slope), high gully networks, poor soil cover, and conservation measures, which have been reported as the main controlling factors for the rate of sediment yield variability in the Tigray catchments $[8,31]$.

The nutrient export rate from the valley was higher than the remaining landforms except the reservoir even though the valley is located at a place where losses can be compensated by imports from the upstream landforms (e.g., mountainous and central ridge). The higher nutrient export from the valley seems to be inconsistent with the point that this landform showed the largest sediment deposits (due to flat slope) next to the reservoir. But the fact for being higher nutrient export by erosion is that the valley received sediment coming from all the other landforms by sediment routing procedure, and such amount of sediment is beyond the capacity of this landform to deposit. Thus, introducing appropriate interventions to the upstream landforms (sources of erosion) that reduce sediment due to water erosion can be the remedy for decreasing the higher nutrient export from the valley landform.

The nutrient export rates from the other landforms showed a well-defined pattern; for example, the mountainous followed by the central ridge landform exported large amounts of nutrients to the valley. Most rates of soil nutrients exported to the aggrading sites in the mountainous area, central ridge, and valley landforms were not significantly $(P>0.05)$ different (Table 3$)$. This indicated that the mountainous and central ridge could be the major sources of the sediment-attached nutrients exported to the valley landform and thereby to the reservoir. The nutrient export rate to the reservoir associated with sediment is higher in the present study catchment when compared to the mean of 13 other catchments in the Tigray region reported by Haregeweyn et al. [13]. However, the nutrient export rate in this study is lower than the findings reported in other subSaharan Africa such as Ghana by Amegashie [32].

A significant $(P<0.05)$ and high coefficient of determination $\left(R^{2}\right)$, that is, $0.87,0.85,0.83,0.78,0.73$, and 0.68 for $\mathrm{Ca}, \mathrm{Pav}, \mathrm{K}, \mathrm{TN}, \mathrm{OC}$, and $\mathrm{Mg}$, respectively, was observed between the nutrients exported and area-specific sediment yield (SSY). This indicated that the SSY accounted for between 68 and $87 \%$ of the variability in the nutrients exported across the landforms. The significant and strong relationships between nutrient export and SSY illustrated that erosion could be the main responsible factor for sedimentattached nutrient export variability among the landforms in the catchment, regardless of the inherent variability of the original soils. Generally, hydrological processes such as erosion can be affected by variability in soil properties, topography, land use/cover, and human-induced changes, and these in turn affect the soil nutrient distribution in landforms $[8,27]$.

The $R^{2}$ (0.68) for the relationship between $\mathrm{Mg}$ and SSY in this study is higher than the $R^{2}(0.29)$ reported in the same study region but in different catchments in Haregeweyn et al. [13]. Some, among the 13 catchments, showed lower nutrient export rates than those estimated for the landforms of this study, and others showed higher nutrient export rates. Despite such differences, the nutrient export rates calculated in the previous and present studies deviated by $<15 \%$, which indicates that the present results hardly under- or overestimate the nutrient export associated with sediment yield. Hence, scaling-up of the present approach to catchments or subcatchments without reservoirs to assess sediment-attached nutrient export is applicable for management planning.

\subsection{Cost of Soil Nutrient Degradation Caused by Erosion.} This study presented the replacement costs related to $\mathrm{N}$ and $\mathrm{P}$ exported by water erosion from the different landforms of the catchment (Table 4). Taking the average value of all landforms may underestimate the replacement cost for the entire catchment as the nutrient transported to the aggrading sites in the landforms was calculated based on the assumption of minimum sediment delivery. The sum of all landforms may also overestimate the replacement cost, because part of the exported nutrients from the upper landforms can be routed to the reservoir and the remaining deposited on the way to the reservoir. We therefore restricted the calculation to nutrients exported to the reservoir from the entire catchment while extrapolating the result of this study. 
TABLE 4: Replacement costs for erosion-associated nutrients exported as $\mathrm{N}$ and $\mathrm{P}$ from the landforms and the entire catchment.

\begin{tabular}{|c|c|c|c|c|c|c|c|c|}
\hline Landform & $\begin{array}{c}\mathrm{N} \\
\text { exported }^{\mathrm{a}} \\
\left(\mathrm{kg} \mathrm{ha}^{-1} \mathrm{y}^{-1}\right)\end{array}$ & $\begin{array}{c}\text { Converted } \\
\text { to urea } \\
\left(\mathrm{kg} \mathrm{ha}^{-1} \mathrm{y}^{-1}\right)\end{array}$ & $\begin{array}{l}\text { Replacement } \\
\text { cost as urea } \\
\left(\mathrm{ETB} \mathrm{ha}^{-1} \mathrm{y}^{-1}\right)\end{array}$ & $\begin{array}{c}\text { P exported } \\
\left(\mathrm{kg} \mathrm{ha}^{-1} \mathrm{y}^{-1}\right)\end{array}$ & $\begin{array}{c}\text { Converted } \\
\text { to DAP } \\
\left(\mathrm{kg} \mathrm{ha}^{-1} \mathrm{y}^{-1}\right)\end{array}$ & $\begin{array}{l}\text { Replacement } \\
\text { cost as DAP } \\
\left(\mathrm{ETB} \mathrm{ha}^{-1} \mathrm{y}^{-1}\right)\end{array}$ & $\begin{array}{c}\text { Total } \\
\mathrm{RC}^{\mathrm{b}, \mathrm{C}} \\
\left(\mathrm{ETB} \mathrm{ha}^{-1} \mathrm{y}^{-1}\right)\end{array}$ & $\begin{array}{l}\text { Total RC per } \\
\text { landform } \\
\left(\mathrm{ETB}^{-1}\right)\end{array}$ \\
\hline Rolling hills & 4.23 & 9.20 & 29.52 & 0.03 & 0.16 & 0.57 & 30.09 & 3,761 \\
\hline Mountainous & 10.36 & 22.52 & 72.32 & 0.08 & 0.43 & 1.55 & 73.86 & 13,443 \\
\hline Central ridge & 8.66 & 18.83 & 60.52 & 0.09 & 0.47 & 1.71 & 62.22 & 19,910 \\
\hline Valley & 11.56 & 25.13 & 80.71 & 0.10 & 0.50 & 1.81 & 82.52 & 20,795 \\
\hline Plateau & 3.92 & 8.52 & 27.33 & 0.02 & 0.11 & 0.39 & 27.72 & 3,354 \\
\hline Escarpment & 7.11 & 15.46 & 49.58 & 0.04 & 0.20 & 0.73 & 50.31 & 12,074 \\
\hline Reservoir & 17.74 & 38.57 & 123.79 & 0.14 & 0.67 & 2.40 & 126.19 & 156,476 \\
\hline Average & 9.08 & 19.75 & 63.39 & 0.07 & 0.36 & 1.31 & 64.70 & 32,830 \\
\hline
\end{tabular}

DAP: diammonium phosphate; ETB: currency, Ethiopian Birr; 17 ETB $€ 1$ in May 2010 on average.

${ }^{\text {a }}$ Part of the $\mathrm{N}$ exported is converted to the $\mathrm{N}$ in DAP.

${ }^{\mathrm{b}} \mathrm{RC}$ : replacement cost for both $\mathrm{N}$ and $\mathrm{P}$ exported as urea and DAP.

${ }^{\mathrm{c}}$ The price of each $100 \mathrm{~kg}$ of urea and DAP in 2010 crop season was 320 and $360 \mathrm{ETB}$, respectively.

${ }^{\mathrm{d}}$ Column 8 multiplied by the area of each landform which is found in Table 2.

The total replacement cost as urea and DAP for the soil nutrients exported ( $\mathrm{N}$ and $\mathrm{P}$ ) from the erosion source areas of the entire study catchment to the reservoir was $126 \mathrm{ETB} \mathrm{ha}^{-1} \mathrm{y}^{-1}$ (€7.40 in May 2010). This value was followed by the valley landform, where the cost was 82.50 $\mathrm{ETB} \mathrm{ha}^{-1} \mathrm{y}^{-1}$ (€5.00). The lowest total replacement cost for the same nutrients exported to the outlet of the plateau landform was $27.70 \mathrm{ETB} \mathrm{ha}^{-1} \mathrm{y}^{-1}(€ 1.60)$, followed by the rolling hills of $30.00 \mathrm{ETB} \mathrm{ha}^{-1} \mathrm{y}^{-1}(€ 1.80)$ (Table 4). The average replacement cost for all landforms including the reservoir was $64.70 \mathrm{ETB} \mathrm{ha}^{-1} \mathrm{y}^{-1}(€ 3.80)$, which was lower than the replacement cost for the reservoir.

The replacement costs estimated for rolling hills, plateau, and escarpment landforms in this study are consistent with the costs estimated by FAO [33] for cropped areas, as they are within the range of 29 to $44 \mathrm{ETB} \mathrm{ha}^{-1} \mathrm{y}^{-1}(€ 1.70-2.60$ in May 2010). But when compared to the replacement costs quantified for the other landforms, the report by FAO [33] underestimated the cost that replaces the nutrients exported ( $\mathrm{N}$ and $\mathrm{P}$ ) as a result of erosion. Alternatively, the replacement cost in the remaining landforms including the reservoir was within the range of the replacement costs estimated for the 13 reservoir catchments in the Tigray region by Haregeweyn et al. [13], regardless of the differences in the foreign currency exchange rate across years.

The total nutrient replacement cost for the entire study catchment (Mai-Negus) was calculated using the cost required to replace the nutrient exported to the reservoir multiplied by the catchment area of $1240 \mathrm{ha}$, that is per annum 156,476 of ETB (€9204 in May 2010). Extrapolation the nutrient replacement cost to the Tigray regional state with a total area of $53,000 \mathrm{~km}^{2}$ ranged from 632 million ETB ( $€ 37.2$ million) to 700 million ETB ( $€ 41.2$ million) and for the Ethiopian highlands that covers $490,000 \mathrm{~km}^{2}$ is estimated from 6.2 billion ETB ( $€ 364$ million) to 7.0 billion ETB ( $€ 412$ million), which are quite impressive figures for researchers, planners, and decision and policy makers to come up with suitable erosion controlling measures. The replacement cost for the Ethiopian highlands accounts for about $8 \%$ of the Ethiopian national annual budget in 2010/11, which is almost twice the Tigray region (northern Ethiopia) annual budget. The above-mentioned replacement costs will become higher if other nutrient losses (e.g., OC, cations) and the losses in physical soil attributes are included. In general, the results of this study can be considered as an indication of the need to implement well-defined and appropriate land use redesign, and soil and water management practices in order to reduce costs related to nutrient replacement, while maintaining sustainable soil productivity in the landforms. The use of inorganic fertilizer as part of the soil management practices is indispensable to replace such nutrients losses. However, this has to be complemented with organic amendments as organic matter sources are locally available. It is also now widely recognized among experts and policy makers that the increasing application of fertilizer at the current prices is not affordable by most farmers and possibly by the government and requires foreign exchange to import fertilizers.

\section{Conclusions}

This study showed that the level of soil degradation ranged from 30 to $80 \%$ in the source soils (eroded site) when compared to the stable sites by the effect of soil erosion. But the severity of degradation was higher in the central ridge and mountainous landforms, which are the main sources of sediment to downstream landforms. The nutrient export rates of OC, TN, Pav, K, Ca, and $\mathrm{Mg}$ showed variability among the landforms, even though significantly higher values were exported into the reservoir. A strong and positive relationship between nutrient export rates and sediment yields also indicated that erosion plays the prime role for nutrient export into the aggrading sites in the landforms. In addition, this study indicated that an annual nutrient replacement cost varied across the landforms, with the highest in the reservoir 
followed by the valley, mountainous, and central ridge landforms. This study thus supports in identifying and prioritizing landforms which are sources of higher nutrient export rates and thereby higher soil degradation, while introducing remedial technologies. The technologies should be targeted to improving soil resistance to erosion and retaining the soil in place just after detachment by raindrops and before transport by runoff from the erosion source areas in the landforms of the study catchment.

\section{Acknowledgments}

The authors gratefully acknowledge the financial support by DAAD/GTZ (Germany) through the Center for Development Research (ZEF), University of Bonn (Germany), and the support of Aksum University (Ethiopia) for the first author's field work. The authors also greatly appreciate the assistance offered by the local farmers and extension agents during the field study.

\section{References}

[1] UNEP (United Nations Environment Program) \& UNESCO (United Nations Educational, Scientific and Cultural Organization), Provision Map of Present Land Degradation Rate and Present State of Soil, FAO, Rome, Italy, 1980.

[2] H. Eswaran, R. Lal, and P. F. Reich, "Land degradation: an overview," in Response to Land Degradation, E. M. Bridges, I. D. Hannam, L. R. Oldeman, F. W. T. Penning de Vries, J. S. Scherr, and S. Sombatpanit, Eds., pp. 20-35, Science Publisher, Enfield, NH, USA, 2001.

[3] H. Hurni, "Land degradation, famine, and land resource scenarios in Ethiopia," in World Soil Erosion and Conservation, D. Pimentel, Ed., pp. 27-62, Cambridge University Press, 1993.

[4] W. Mekuria, E. Veldkamp, M. Haile, J. Nyssen, B. Muys, and K. Gebrehiwot, "Effectiveness of exclosures to restore degraded soils as a result of overgrazing in Tigray, Ethiopia," Journal of Arid Environments, vol. 69, no. 2, pp. 270-284, 2007.

[5] P. L. G. Vlek, Q. B. Le, and L. Tamene, "Assessment of land degradation, its possible causes and threat to food security in Sub-Saharan Africa," in Advances in Soil Sciences Food Security and Soil Quality, R. Lal and B. A. Stewart, Eds., pp. 57-86, CRC Press, Boca Raton, Fla, USA, 2010.

[6] P. Dubale, "Soil and water resources and degradation factors affecting productivity in Ethiopian highland agro-ecosystems," Northeast African Studies, no. 8, pp. 27-52, 2001.

[7] S. Damene, L. Tamene, and P. L. G. Vlek, "Performance of exclosure in restoring soil fertility: a case of Gubalafto district in North Wello Zone, northern highlands of Ethiopia," Catena, vol. 101, pp. 136-142, 2013.

[8] L. Tamene, Reservoir siltation in the drylands of northern Ethiopia: causes, source areas and management options [Ph.D. thesis], Center for Development Research, University Bonn, Bonn, Germany, 2005.

[9] W. D. Ellison, "Fertility Erosion,” The Land, vol. 9, p. 487, 1950.

[10] G. M. Hashim, K. J. Coughlan, and J. K. Syers, "On site nutrient depletion: an effect and a cause of soil erosion," in Soil Erosion at Multiple Scales: Principles and Methods For Assessing Causes and Impacts, F. W. T. Penning de Vries, F. Agus, and J. Kerr, Eds., pp. 207-221, CAB International, 1998.
[11] J. J. Stoorvogel and E. M. A. Smaling, "Assessment of soil nutrient depletion in Sub-Saharan Africa, 1983-2000," Report 28, DLO Winand Staring Center for Integrated Land, Soil and Water Research, Wageningen, The Netherlands, 1990.

[12] UNDP (United Nations Development Programme), Technical Note on the Environment, DCGE, Addis Ababa, Ethiopia, 2002.

[13] N. Haregeweyn, J. Poesen, J. Deckers et al., "Sediment-bound nutrient export from micro-dam catchments in Northern Ethiopia," Land Degradation and Development, vol. 19, no. 2, pp. 136-152, 2008.

[14] J. R. Stone, J. W. Gilliam, D. K. Cassel, R. B. Daniels, L. A. Nelson, and H. J. Kleiss, "Effect of erosion and landscape position on the productivity of Piedmont soils," Soil Science Society of America Journal, vol. 49, no. 4, pp. 987-991, 1985.

[15] W. R. Kreznor, K. R. Olson, W. L. Banwart, and D. L. Johnson, "Soil, landscape, and erosion relationships in a northwest Illinois watershed," Soil Science Society of America Journal, vol. 53, no. 6, pp. 1763-1771, 1989.

[16] E. Elias, S. Morse, and D. G. R. Belshaw, "Nitrogen and phosphorus balances of Kindo Koisha farms in southern Ethiopia," Agriculture, Ecosystems and Environment, vol. 71, no. 1-3, pp. 93-113, 1998.

[17] I. Scoones, Ed., Dynamics and Diversity: Soil Fertility and Farming Livelihoods in Africa: Case Studies From Ethiopia, Mali and Zimbabwe, Earthscan Publications Ltd, London, UK, 2001.

[18] S. K. Papiernik, T. E. Schumacher, D. A. Lobb et al., "Soil properties and productivity as affected by topsoil movement within an eroded landform," Soil and Tillage Research, vol. 102, no. 1, pp. 67-77, 2009.

[19] G. W. Gee and J. W. Bauder, "Particle-size analysis," in Methods of Soil Analysis. Part 1, A. Klute, Ed., pp. 383-411, American Society of Agronomy, Soil Science Society of America, Madison, Wis, USA, 2nd edition, 1986.

[20] G. R. Blake and K. H. Hartge, "Bulk Density," in Methods of Soil Analysis. Part 1, A. Klute, Ed., vol. 9 of Agronomy Monograph, pp. 363-375, American Society of Agronomy, Madison, Wis, USA, 2nd edition, 1986.

[21] J. M. Bremmer and C. S. Mulvaney, "Nitrogen total," in Method of Soil Analysis. Part 2. Chemical and Microbiological Properties, A. L. Page, Ed., vol. 9 of Agronomy Monograph, pp. 595-624, American Society of Agronomy, Madison, Wis, USA, 1982.

[22] S. R. Olsen and L. E. Sommers, "Phosphorus," in Method of Soil Analysis. Part 2. Chemical and Microbiological Properties, A. L. Page, Ed., vol. 9 of Agronomy Monograph, pp. 403-430, American Society of Agronomy, Madison, Wis, USA, 1982.

[23] J. M. Anderson and J. S. I. Ingram, Tropical Soil Biology and Fertility. A Handbook of Methods, CAB International, Wallingford, UK, 1993.

[24] J. D. Rhoades, "Cation exchange capacity," in Methods of Soil Analysis. Part 2, A. L. Page, R. H. Miller, and D. R. Keeney, Eds., vol. 9 of Agronomy Monograph, pp. 149-157, American Society of Agronomy, Madison, Wis, USA, 1982.

[25] T. C. Baruah and H. P. Barthakur, A Text Book of Soil Analysis, Vikas Publishing House, New Delhi, India, 1999.

[26] G. Verstraeten and J. Poesen, "Regional scale variability in sediment and nutrient delivery from small agricultural watersheds," Journal of Environmental Quality, vol. 31, no. 3, pp. 870-879, 2002.

[27] G. B. Tesfahunegn, "Soil erosion modeling and soil quality evaluation for catchment management strategies in northern Ethiopia," Ecology and Development Series No. 83, Center for 
Development Research, University of Bonn, Bonn, Germany, 2011.

[28] J. Bojö, "The costs of land degradation in Sub-Saharan Africa," Ecological Economics, vol. 16, no. 2, pp. 161-173, 1996.

[29] SPSS (Statistical Package for Social Sciences), Statistical Package For Social Sciences. Release 18.0, SPSS Inc., 2011.

[30] A. Haileslassie, J. Priess, E. Veldkamp, D. Teketay, and J. P. Lesschen, "Assessment of soil nutrient depletion and its spatial variability on smallholders' mixed farming systems in Ethiopia using partial versus full nutrient balances," Agriculture, Ecosystems and Environment, vol. 108, no. 1, pp. 1-16, 2005.

[31] J. Nyssen, J. Poesen, J. Moeyersons, M. Haile, and J. Deckers, "Dynamics of soil erosion rates and controlling factors in the Northern Ethiopian highlands-towards a sediment budget," Earth Surface Processes and Landforms, vol. 33, no. 5, pp. 695711, 2008.

[32] B. K. Amegashie, Assessment of catchment erosion, sedimentation and nutrient export into small reservoirs from their catchments in the upper east region of Ghana [M.S. thesis], Kwame Nkrumah University of Science and Technology, Kumasi, Ghana, 2009.

[33] FAO (Food and Agriculture Organization of the United Nations), "Ethiopian highland reclamation study," Final Report, FAO, Rome, Italy, 1986. 

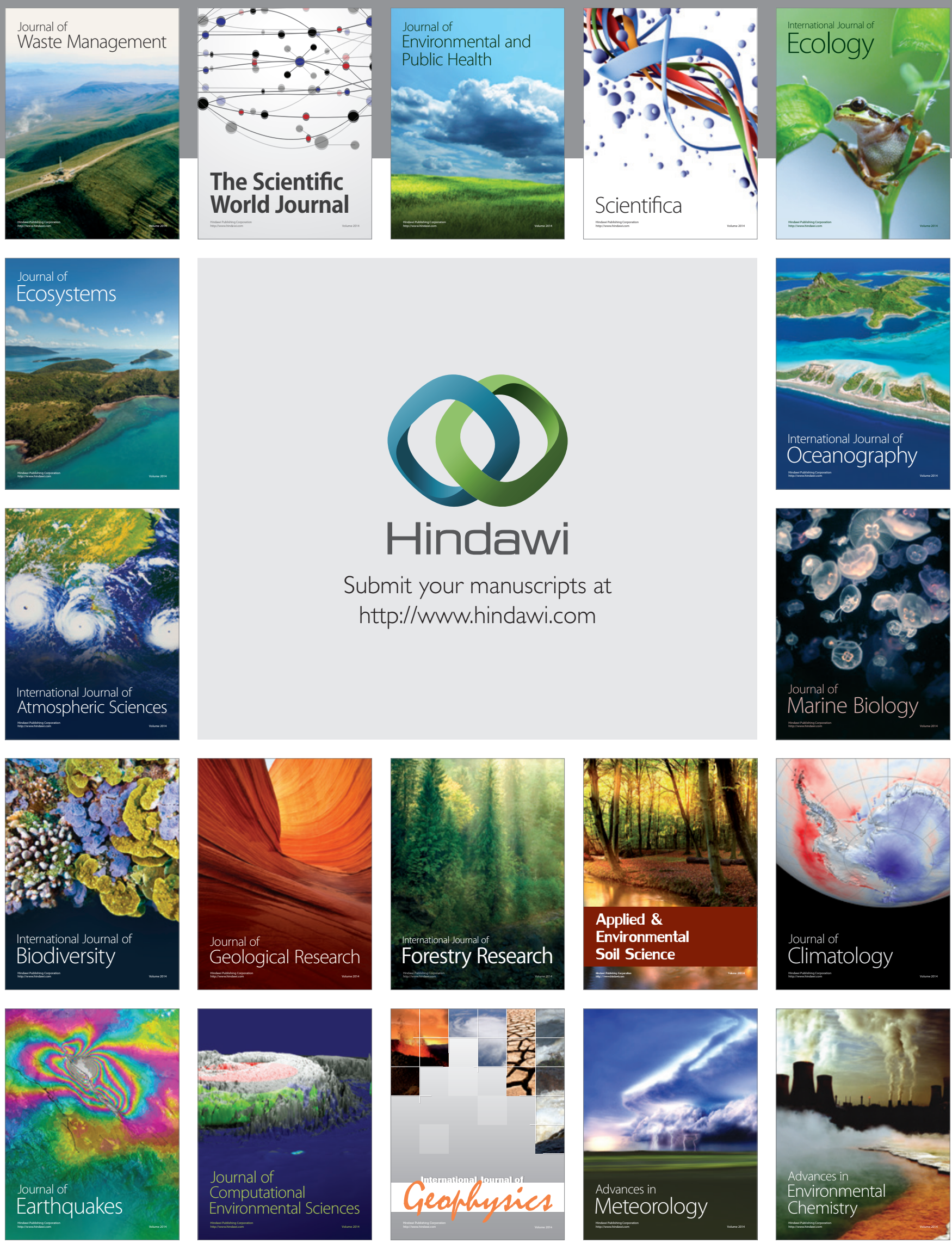